\title{
"A Revolta dos Pingüins" e o novo pacto educacional chileno
}

\author{
Dagmar M. L. Zibas \\ Fundação Carlos Chagas
}

\section{Introdução: \\ o objeto de estudo e sua relevância}

Em 30 de maio de 2006, a mídia internacional, principalmente a latino-americana, deu destaque a tumultuadas cenas de rua que se multiplicavam em cidades do Chile. Tais cenas, consideradas episódios inusitados nas últimas três décadas da história daquele país, eram protagonizadas por estudantes secundaristas - maciçamente mobilizados em nível nacional - que entraram em greve, tomaram as escolas, organizaram assembléias e saíram em passeatas, gritando palavras de ordem que sintetizavam um discurso político há muito tempo ausente do cenário estudantil chileno. ${ }^{1}$

\footnotetext{
${ }^{1}$ A primeira entidade que congregou estudantes chilenos (Federación de Estudiantes de Universidad de Chile-FECH) foi fundada em 1906 e sempre teve grande protagonismo nos movimentos políticos, contribuindo, por diversas vezes, para o avanço da democracia no país. No entanto, a partir da ditadura de Pinochet e passando pelos últimos 17 anos de governos democráticos, não houve mobilização estudantil de expressão. Daí a surpresa e um certo imobilismo inicial dos órgãos
}

Ganhando adesão das famílias e de várias organizações da sociedade civil, o movimento dos "pingüins" (assim chamados por seu uniforme ao estilo do início do século passado) abalou o governo recém-empossado de Michelle Bachelet, obrigando à realização de reuniões ministeriais de emergência, pronunciamentos do Legislativo, dos empresários, manifestações do sindicato docente (denominado Colégio de Professores), das universidades e de outras entidades. A subseqüente demissão do ministro de Educação foi um fato traumático para as esferas oficiais, com grande repercussão nos meios de comunicação e na área política.

Em vista do papel central que, nos anos de 1990, o modelo chileno desempenhou no desenho das reformas educacionais de quase todos os países vizinhos, é muito compreensível o grande interesse da mídia internacional em divulgar a "Revolta dos Pingüins", assim como é justificável o esforço dos meios acadêmicos latino-americanos no sentido de compreender as raízes daquela mobilização e seus desdobramentos.

oficiais ante o ineditismo, nos últimos 30 anos, dos protestos e das reivindicações dos alunos secundaristas. 
De fato, na década passada, as três características mais marcantes do sistema educacional chileno - a descentralização da gestão, a subvenção pública à demanda (ou por aluno presente na sala de aula), tanto na rede municipal quanto na rede privada, e o "financiamento compartido", isto é, a permissão de que escolas subvencionadas cobrem mensalidades às famílias - foram constantemente destacadas por agências internacionais, por empresários e por diversos especialistas como exemplos a serem seguidos pela América Latina. Como se sabe, o Brasil não ficou totalmente imune a essa "investida neoliberal", havendo aqui muita divulgação do pretendido sucesso da reforma chilena (Mello, 1990; Tedesco, 1991; Instituto Herbert Levy, 1992). Desde o início desta década, no entanto, as evidências de aprofundamento da segmentação educacional no Chile levaram alguns dos seus arautos à elaboração de um discurso mais crítico sobre as reformas (Tedesco, 2001). Uma avaliação mais contundente foi feita pela Organização para a Cooperação e o Desenvolvimento Econômicos (OCDE), nos seguintes termos:

[...] a educação chilena parece estar conscientemente estruturada por classes sociais [...] está influenciada por uma ideologia que dá importância indevida aos mecanismos de mercado para melhorar o ensino e a aprendizagem. (OCDE, 2004, p. 290, tradução livre)

Em que pesem os reveses registrados, há aspectos inovadores das políticas chilenas que, para o bem e para o mal, se tornaram paradigmas inescapáveis para todo o continente. O Sistema de Medición de la Calidad de la Educación (SIMCE) foi o precursor de programas de avaliação de sistemas, inaugurados posteriormente em toda a região, inclusive, como se sabe, no Brasil. O programa de financiamento compensatório destinado a escolas mais carentes (Programa das 900 Escolas - P-900) também foi bastante difundido regionalmente, originando iniciativas semelhantes em diversos países. Há, ainda, inovações mais recentes que têm obrigado os educadores latino-americanos a voltar sua atenção para o sistema chileno. O estabe- lecimento da Jornada Escolar Completa $(\text { JEC })^{2}$ para toda a escola fundamental e média, o ensino médio obrigatório e o acordo entre governo e sindicato docente que estabeleceu a avaliação periódica de todos os professores são novas faces do modelo chileno que devem ser acompanhadas com cuidado por pesquisadores brasileiros. Adicionalmente, o último resultado da prova internacional Programme for Indicators of Students Achievement (PISA), referente ao ano de 2005, com todas as restrições técnicas e políticas que se possam fazer a esse teste, colocou os alunos do Chile em primeiro lugar entre os latino-americanos, o que parece exigir uma reflexão um pouco mais profunda sobre alguns aspectos da política educacional daquele país.

A pesquisa que realizei em Santiago, ${ }^{3}$ entre novembro e dezembro de 2007, teve o objetivo de traçar um amplo painel do atual debate educacional no Chile, estudando algumas características do movimento estudantil chileno e seus atuais desdobramentos legais, políticos e institucionais, de forma a trazer subsídios para a discussão do nosso próprio sistema de ensino.

\section{O contexto}

Sabe-se que a dificuldade de pesquisa de outras realidades nacionais está principalmente no fato de que devem sempre ser levadas em conta na análise pretendida as distâncias históricas, sociais e econômicas, que não são de imediata apreensão pelo investigador estrangeiro. Um dos erros dos organismos internacionais, ao analisar os problemas da educação latino-americana, tem sido precisamente ignorar as diferenças históricas e sociais entre os distintos países focalizados.

2 A JEC foi estabelecida nesta década em todo o sistema escolar chileno. Com ela, o tempo escolar diário, para todos os alunos, estende-se em geral das 8 horas da manhã até às 16 h.

3 A pesquisa foi financiada pela Fundação de Amparo à Pesquisa do Estado de São Paulo (FAPESP) e o projeto original teve o título "Desdobramentos atuais da reforma educativa chilena dos anos 1980/1990”. 
Nesta leitura da realidade chilena por uma pesquisadora brasileira, talvez não seja supérfluo enfatizar o fato de que nossa população é pelo menos dez vezes superior à chilena, a qual foi estimada, em 2007, em pouco mais de 16,5 milhões de habitantes. De outra parte, aquele país, já em 1810, como reação à invasão da Espanha por Napoleão, declarou-se uma República, embora ainda fiel à derrotada Coroa espanhola. Em 1818, o país conseguiu sua independência completa da Espanha. O Chile teve, pois, a possibilidade de iniciar, 71 anos antes de nós, a consolidação das instituições de um estado republicado moderno. Já em 1860, a Lei Orgânica da Instrução Primária estabelecia no Chile que o ensino das primeiras letras deveria ser gratuito, universalizado (ou seja, para todas as classes sociais e para ambos os sexos) e sob a responsabilidade do governo nacional. Em 1920, a universalização foi transformada em obrigatoriedade (Nuñes Prieto, 2000). Como se sabe, no Brasil a obrigatoriedade do ensino primário só foi instituída constitucionalmente na década de 1930, mas permitindo ainda uma relativização, já que era dispensada quando os pais fossem muito pobres ou quando não houvesse escolas nas proximidades.

No Chile, a atual cobertura praticamente plena desde o ensino fundamental até o ensino médio - do sistema educacional é, sem dúvida, herdeira da história precoce de universalidade e obrigatoriedade de seu ensino primário. Em contrapartida, essa cobertura plena também pode ser compreendida pelo ângulo da pequena população demandante. Por exemplo, em 2005, no que diz respeito ao ensino médio, a cobertura plena representava 1.029.366 matrículas, aí incluídas as inscrições na modalidade técnico-profissional (Chile, 2005). No Brasil, o ensino médio regular em 2005 contava com mais de nove milhões de matrículas, estando, porém, muito longe de acolher toda a população jovem entre 15 e 17 anos. Além dessa grande disparidade quantitativa, é preciso destacar as diferenças de estrutura entre os sistemas educativos dos dois países. Nesse sentido, o exíguo tempo que nossos alunos passam diariamente na escola contrasta com a JEC (dois períodos) a que estão submetidos todos os alunos da escola fundamental e média no Chile. Adicionalmente, como se sabe, o ensino médio noturno tem grande relevância no Brasil, abrigando não só adultos como também grande contingente de adolescentes, principalmente aqueles que já trabalham. Tal desvio está ausente do sistema chileno, onde a escola noturna é exceção e reservada exclusivamente para adultos com atraso escolar.

De outra parte, é necessário enfatizar que as inscrições na rede privada subvencionada pelo Estado chileno em 2005 já alcançavam 43\% do total de matrículas no ensino fundamental (lá denominado enseñanza básica) e médio. No mesmo ano, as escolas municipais atendiam $49 \%$ do total de alunos desses dois níveis de ensino e as particulares não subvencionadas detinham 8\% das inscrições (idem).

$\mathrm{O}$ avanço da rede privada subvencionada é uma questão nevrálgica nas disputas políticas no Chile. Sobre esse tema, é importante destacar o fato de que foi a iniciativa de um governo democrático, pós-Pinochet, que aprofundou a privatização do sistema educacional, ao permitir, em 1993, por meio da Ley de Impuestos a la Renta, que os estabelecimentos particulares subvencionados cobrassem mensalidades de alunos do ensino fundamental e médio. Tal liberalidade também foi concedida às escolas municipais de ensino médio (liceus) (Almonacid, s.d.; Rojas Figueroa, 1997), as quais, entretanto, por abrigar a população mais pobre, nunca puderam, em sua grande maioria, contar com esses recursos. Nesse contexto, até recentemente, ${ }^{4}$ o financiamento estatal das escolas particulares não tinha um fator equilibrado de regressão/progressão que compensasse o aporte financeiro das famílias ao sistema privado subvencionado e que considerasse os custos necessariamente mais elevados da educação dos

\footnotetext{
${ }^{4} \mathrm{O}$ programa inaugural do Governo Bachelet já previa
} alguma correção do financiamento do sistema, aumentando a subvenção às matrículas de alunos mais pobres. O projeto da Lei de Financiamento Preferencial, em tramitação no Congresso, foi elaborado antes do "movimento dos pingüins" e será tratado mais adiante 
mais pobres, quase exclusivamente a cargo das escolas municipais. Em outras palavras: o sistema gerido por empresários ou por entidades religiosas, embora cobrando mensalidades dos pais e pouco atendendo à clientela de mais baixo nível socioeconômico, tem recebido financiamento oficial, por aluno, praticamente idêntico àquele concedido às escolas municipais, sendo que essas últimas atendem aos filhos das famílias mais pobres e não contam, em geral, com o aporte financeiro dos pais.

Além disso, o lucro dos proprietários das escolas subvencionadas tem sido considerado legítimo por muitos setores da sociedade chilena, e a seleção de pretendentes à matrícula nessas escolas também sempre foi tolerada pelo governo central. A distribuição desequilibrada dos recursos públicos - aliada à seletividade do sistema privado - apenas tende a tornar a rede municipal um gueto dos alunos mais pobres (Zibas, 2002), reiterando, durante anos, a isonomia entre rendimento escolar dos alunos e nível socioeconômico das famílias. ${ }^{5}$ O Gráfico 1 , com uma configuração em escada, evidencia de modo muito claro que os resultados obtidos por estudantes nas provas padronizadas (SIMCE) estão diretamente relacionados à renda familiar.

\section{Pontuação}

É importante, também, notar que os investimentos do governo central no sistema educacional se têm mantido, desde 1996, abaixo de 4,0\% do Produto Interno Bruto (PIB), atingindo essa percentagem apenas em 2003. Para 2007, aquele montante estava estimado em 3,6\% do PIB, conforme pode ser observado no Gráfico 2.

Em contrapartida, se somarmos os investimentos do governo central aos aportes financeiros que os municípios mais ricos fazem em seus sistemas de ensino

${ }^{5}$ Ao fazer essa observação, não se pode ignorar que a mesma relação acontece no Brasil, onde a escola básica, pública e gratuita se torna cada vez mais concentradora de filhos das camadas mais pobres da população, ao mesmo tempo em que sua qualidade vai ficando cada vez mais precária.
Gráfico 1: Resultados do SIMCE no $4^{\circ}$ ano básico - 2002, segundo decil do nível socioeconômico das famílias dos estudantes

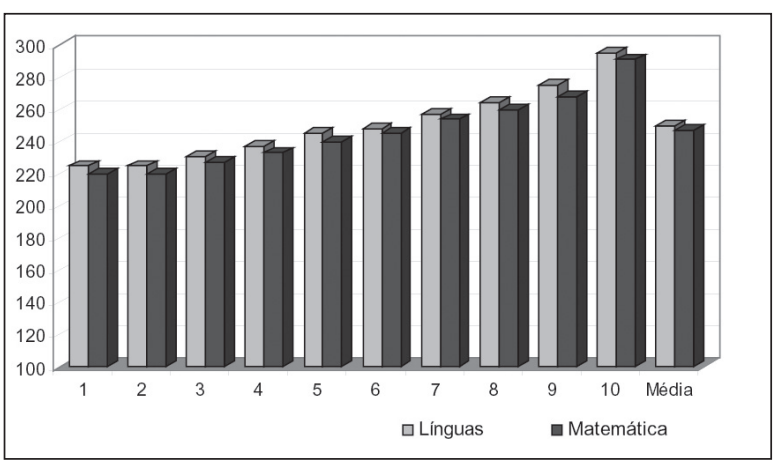

Fonte: SIMCE, Ministério da Educação (MINEDUC), apud Mizala (2007, p. 165).

Gráfico 2: Gastos públicos, em porcentagem do PIB.

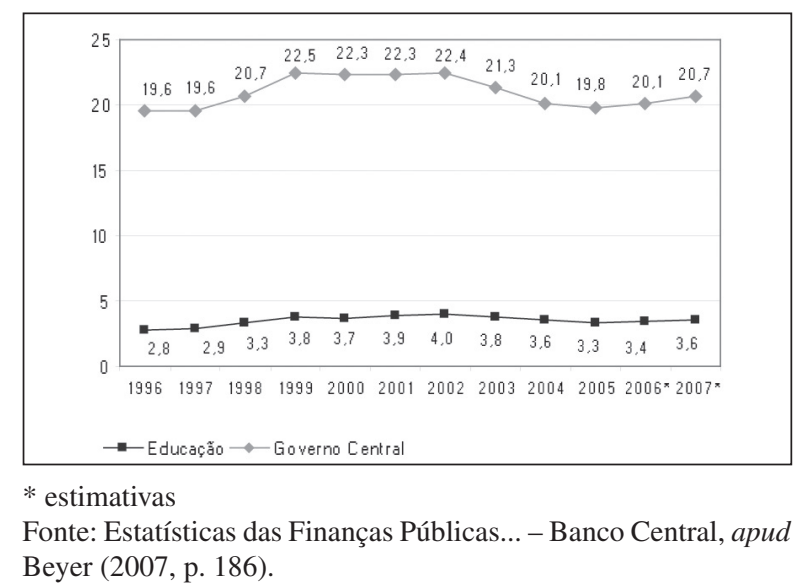

e as mensalidades pagas pelas famílias, o investimento chileno em educação sobe a 6,4\% do PIB (em 2004). Essa estatística é usada por alguns analistas para justificar a desnecessidade de maior investimento estatal em educação (Nuñes Prieto, 2007, p. 2).

\section{Da "Revolta dos Pingüins" ao novo pacto educacional}

No início das mobilizações, em 2006, a primeira pauta de reivindicações dos estudantes era muito simples e carecia da dimensão política que veio a ganhar mais tarde. Constava principalmente dos seguintes itens: gratuidade do exame de seleção para a univer- 
sidade, passe escolar grátis e sem restrições de horário para transporte municipal, melhoria e aumento da merenda escolar e reforma das instalações sanitárias em mau estado em muitas escolas. Essas questões foram quase imediatamente equacionadas ou atendidas pelo governo da presidenta Bachelet. Todavia, a ampliação do debate nas assembléias estudantis e a adesão de outros agentes políticos, como o sindicato docente, vieram dar maior profundidade e amplitude à pauta inicial, que passou a incluir, entre outros pontos, a anulação da Lei Orgânica Constitucional de Ensino $(\mathrm{LOCE})^{6}$ e a modificação ou anulação da JEC.

Durante o período das maciças e tensas manifestações estudantis de 2006, foi criado pela presidenta Bachelet o Conselho Assessor Presidencial, presidido pelo respeitado especialista Juan Eduardo Garcia-Huidobro, que reuniu representantes dos diversos agentes do sistema educativo: empresários da educação, pesquisadores, professores, gestores, sindicalistas, pais e alunos. O objetivo de tal conselho era propor mudanças na legislação educacional, de modo que conciliasse as reivindicações dos vários grupos sociais provocados a se expressar a partir do movimento dos "pingüins". No entanto, o relatório final do colegiado não conseguiu construir um consenso que acomodasse o grande espectro de interesses, valores e ideologias defendidos pelos setores representados. Assim, o documento final foi rejeitado por um grupo dissidente (Bloco Social pela Educação), composto essencialmente por estudantes, professores e pais.

Ao discordar dos encaminhamentos do Conselho Assessor Presidencial, os estudantes tentaram, em meados de 2007, nova mobilização. No entanto, o clima político já era outro, e dessa vez não houve condições de construção de um discurso unitário que sensibilizasse as diferentes correntes do setor estudantil. Além disso, como será discutido mais adiante, há indícios de que a repressão ao movimento já estava

${ }^{6}$ A LOCE foi instituída por Pinochet em seu último dia como presidente da República e, apesar dessa lamentável origem ditatorial, foi preservada por todos os governos eleitos a partir de 1990 . mais bem organizada, o que pode ter impedido a generalização dos novos protestos.

O influente especialista José Joaquin Brunner opinou sobre os resultados dos trabalhos do Conselho Assessor Presidencial nos seguintes termos:
[...] caso se procure no relatório uma proposta coerente, orgânica e unitária de melhoria da educação, não se encon- trará. Na verdade, nem se podia esperar isso, em vista da origem, da natureza, da composição e do método de trabalho do Conselho [...] criado para levantar um leque de soluções de política. E cumpriu o prometido. (Brunner, 2006, p. D4, tradução livre)

De toda forma, em abril de 2007, com base nos arrazoados do relatório final do conselho, a presidenta Michelle Bachelet convocou outras autoridades, a imprensa e representantes de diversos segmentos da sociedade para apresentar seu projeto da nova Lei Geral de Educação (LGE), que substituiria a LOCE. Embora fosse evidente para muitos setores que a LOCE, ainda herança da Ditadura Pinochet, carecia de legitimidade política e social, devendo mesmo ser substituída, a nova LGE causou imediatamente grande controvérsia. Seus pontos polêmicos eram os seguintes: eliminação da possibilidade de seleção de candidatos à matrícula até a $8^{\mathrm{a}}$ série do ensino fundamental, proibição da obtenção de lucro por parte das escolas privadas subvencionadas com verbas oficiais e maior exigência de pré-requisitos aos responsáveis por tais escolas.

Os partidos de oposição, comumente chamados "de direita", 7 reunidos no bloco denominado Alianza, acusaram o projeto oficial de não assegurar a liberdade de ensino nem resolver os problemas de qualidade,

${ }^{7}$ No Chile, todo o espectro político está formalmente aglutinado em dois blocos: a Concertación, que abriga os partidos que há 17 anos, desde a queda da ditadura de Pinochet, vencem as eleições e compartilham o governo do país, e a Alianza, que agrega os partidos que fazem oposição ao governo. Embora, como era de se esperar, em cada bloco haja nuanças ideológicas diferenciadas e, algumas vezes, contraditórias, é convenção considerar-se a Concertación como "de esquerda" e a Alianza como "de direita". 
além de ideologizar a educação. Economistas apontaram que a proposta desqualificava a iniciativa privada. Alguns dos liceus municipais, denominados "paradigmáticos" ou de excelência, com sólida reputação de qualidade baseada em rigorosa seleção de alunos, passaram a discutir as vantagens e desvantagens de seu tradicional processo seletivo. Finalmente, a Igreja católica, grande beneficiária do financiamento público da escola privada, levantou forte crítica ao projeto, invocando seu tradicional argumento da intocável "liberdade de escolha das famílias no que diz respeito à educação dos filhos" (Errázuriz, 2007, p. D1).

Essa mobilização dos setores conservadores teve evidentemente grande repercussão no Congresso, onde o governo não conseguiu maioria para a aprovação da LGE. Em contrapartida, o bloco opositor Alianza lançou, em julho de 2007, um projeto alternativo, em um documento de 36 páginas, em que o binômio "qualidade/liberdade" se torna uma enfática defesa do financiamento público da escola privada e do direito ao lucro na educação subvencionada.

Diante da impossibilidade de aprovação de seu projeto original, o Executivo propôs à Alianza, ainda em julho de 2007, a formação de um comitê pluripartidário que estudasse os pontos de acordo entre os dois projetos em disputa. Aceita a proposta, as reuniões do comitê estenderam-se de agosto a novembro. Em começo de novembro de 2007, a versão final do acordo obtido começou a ser conhecida (Gobierno de Chile, Alianza y Concertación, 2007). Alguns dos principais pontos acordados foram os seguintes:

\section{Mudança nos níveis do sistema}

O ensino fundamental (enseñanza básica) foi reduzido de oito para seis anos. O ensino médio foi ampliado de quatro para também seis anos, sendo que as duas últimas séries desse nível se transformarão em cursos de especialização, compreendendo três ramos: científico, humanístico e técnico-profissional. A mudança baseou-se no argumento de que a partir da $7^{\mathrm{a}}$ série os alunos necessitariam de professores especializados, tal como no ensino médio, uma vez que os professo- res generalistas (até agora dedicados às oito séries do ensino fundamental) seriam adequados apenas para as seis primeiras séries. A especialização nos dois últimos anos do ensino médio foi entendida como necessária para atender a diversidade de objetivos dos adolescentes; no entanto, a técnicoprofissional restringirá posteriores opções por cursos superiores.

\section{Pré-seleção de alunos}

Para as escolas que recebem subvenção, fica proibida a seleção de candidatos a matrículas desde a pré-escola até a $6^{\mathrm{a}}$ série (e não até a $8^{\mathrm{a}}$ série, como propunha o governo). Ou seja, deve ser abolida (até a 6 a série) a prática, muito comum na rede particular subvencionada, de selecionar seus alunos de acordo com o "rendimento passado ou potencial do candidato" ou de acordo com os "antecedentes socioeconômicos da família". No entanto, mesmo nessas séries iniciais, as crenças religiosas poderão ser, sim, um tema de seletividade, apoiada, nesse caso, no argumento de "particularidades do projeto educacional da escola". Nesse aspecto, prevaleceu a posição da Igreja católica, que sempre manteve uma atitude crítica com respeito ao discutido fim da seleção. A partir da $6^{\mathrm{a}}$ série, os critérios de seleção poderão ser baseados em padrões acadêmicos, continuando válida a seleção subordinada às características da proposta institucional (ensino religioso, por exemplo), aí incluídos aspectos de disciplina e de conduta. Entretanto, os critérios seletivos devem ser transparentes e informados detalhadamente às famílias. Em todos os casos, a renovação da matrícula poderá ser negada se os pais se mostrarem incapazes de arcar com o custo da mensalidade escolar.

Condições que permitem obtenção de lucro pelos empresários da educação e criação da Superintendência da Educação

Continua permitido que os proprietários privados de escolas subvencionadas tenham lucro, mas 
devem ser pessoas jurídicas, dedicadas somente ao ramo da educação. Além disso, os proprietários devem ter estudos de nível superior. Os gastos dos recursos recebidos do governo central deverão ser fiscalizados por uma Superintendência de Educação, a ser implantada. Tal entidade será um serviço público funcionalmente descentralizado, dotado de personalidade jurídica e patrimônio próprio, que se relacionará com o presidente da República por meio do MINEDUC. O superintendente será designado pelo presidente da República a partir de uma lista tríplice proposta pelo Conselho da Alta Direção Pública. A nova entidade poderá punir de diversas formas os estabelecimentos que cometerem infrações referentes aos requisitos de operação e funcionamento.

\section{Agência de qualidade}

Foi acolhida a sugestão da oposição de criar uma agência, independente do MINEDUC e da Superintendência da Educação, dirigida por uma comissão técnica de alto nível. As avaliações do desempenho do sistema, das escolas e dos professores estarão sob responsabilidade dessa agência autônoma, que realizará diagnósticos e apoiará o trabalho das escolas, sendo tal apoio maior no caso das mais deficitárias. Suas recomendações não serão obrigatórias, mas o mau desempenho provocará sanções que vão desde a perda do direito à subvenção até o fechamento da escola. Tais sanções valem tanto para as escolas municipais quanto para as particulares subvencionadas. A diretoria da agência será composta de cinco membros, com mandato de seis anos, escolhidos pela presidência da República em lista a ser apresentada pelo Conselho da Alta Administração Pública.

\section{Conselho Nacional de Educação}

Esse conselho será um organismo autônomo, que se relacionará com o presidente da República por meio do MINEDUC. Será constituído por dez conselheiros, sendo três deles designados pelo Executivo, quatro por aprovação de $2 / 3$ do Senado e três eleitos diretamente por instâncias do sistema educacional. Suas atribuições serão, principalmente, aprovar bases curriculares, planos e programas para o ensino fundamental e médio elaborados pelo MINEDUC, analisar os planos de avaliação dos objetivos fundamentais da aprendizagem e assessorar o ministro da Educação.

Esses pontos acordados deram um outro perfil ao projeto da LGE. O projeto assim modificado foi novamente encaminhado para aprovação do Congresso, no início de 2008.

\section{Aspectos polêmicos da política educacional que não foram incluídos no acordo}

\section{Itens reivindicados pelos estudantes}

Importantes reivindicações dos estudantes foram omitidas pelo acordo: a revisão da JEC, o fim do lucro em educação, o estabelecimento de menor número de alunos por classe e a extensão do currículo para incluir formação sindical e educação sexual. Algumas repercussões dessas omissões serão discutidas mais adiante.

\section{Financiamento "compartido"}

Apontado como uma das principais causas da profunda segmentação educacional existente no Chile, o "financiamento compartido" - a liberdade das escolas subvencionadas de cobrar mensalidades às famílias - continua vigente, não tendo sido abordado pelo pacto.

\section{Subvenção preferencial}

A questão da "subvenção preferencial" é apenas marginalmente mencionada no acordo, uma vez que, conforme já explicitado, se trata de proposta de lei apresentada pelo governo ao Congresso antes da mobilização dos estudantes. Todavia, há críticas bem fundamentadas a essa inovação, que também serão discutidas em item seguinte. 
Municipalização/desmunicipalização e o estatuto docente

Esses são aspectos correlatos do debate educacional chileno sobre os quais não foi possível estabelecer consenso entre governo e oposição, tendo ambos sido omitidos pelo pacto. Na verdade, a municipalização sempre foi um tema polêmico da reforma chilena desde sua implementação durante o Governo Pinochet. Desde então, o MINEDUC continuou com a responsabilidade pelo cumprimento do currículo mínimo nacional, pela elaboração e distribuição de material didático e pelo controle da qualidade, enquanto os municípios administram as verbas recebidas do governo central e supervisionam as unidades escolares e seus quadros de pessoal, inclusive os contratos de professores. ${ }^{8}$ Todavia, a resistência dos docentes conseguiu que o seu estatuto continuasse válido para todo o sistema municipalizado. Ou seja, as normas para o magistério têm abrangência nacional no que diz respeito à admissão à carreira, salários, progressão e estabilidade funcional. Nesse sentido, o estatuto docente é um dos últimos baluartes da resistência à introdução de leis de mercado na educação chilena, constituindo um resquício do "Estado docente" que prevaleceu até a chegada de Pinochet ao poder. Até por ser considerado símbolo de políticas que privilegiam o papel do Estado, o estatuto docente está constantemente em litígio, sendo criticado ou defendido por diferentes setores do espectro político e acadêmico do Chile. $\mathrm{O}$ vigor de tal embate não permitiu que as negociações entre o governo e a oposição tratassem do tema. Além disso, há diferenças entre os municípios quanto aos investimentos em educação: os mais ricos podem complementar o financiamento

\footnotetext{
${ }^{8}$ É preciso lembrar que o Chile não é uma República federativa, mas centralizada. Assim, os municípios são as entidades políticas mais importantes depois do governo nacional, com o qual se relacionam diretamente. As 15 regiões em que se agrupam os municípios são simples unidades administrativas, cujos titulares não são eleitos, mas nomeados diretamente pela Presidência da República.
}

advindo do governo central e aportar prêmios e outras bonificações aos docentes, enquanto outros não podem conceder qualquer financiamento extra às escolas ou aos professores. ${ }^{9}$ De outra parte, somente $10 \%$ dos 345 municípios existentes contam, em seu organograma, com um departamento de educação, o que indica que os demais não têm sequer estrutura para gerir a educação municipalizada. Essas conhecidas fragilidades fazem com que os partidos da Concertación acenem para a possibilidade de estabelecer, mais adiante, outras unidades administrativo-educacionais, correspondentes às 15 regiões em que se divide o país ou constituídas por outros critérios. Entretanto, essas propostas não foram incluídas no pacto, em vista das restrições dos partidos da Alianza.

\section{SIMCE}

Embora durante a negociação do pacto não tenha havido qualquer focalização no SIMCE por parte de nenhum dos setores envolvidos, a aplicação e o uso dos resultados dessa prova-padrão têm sido questões geradoras de grande controvérsia. $\mathrm{Na}$ verdade, esse instrumento é apontado como o único balizamento da política educacional e, como tal, acusado de empobrecer todo o processo. Em vista de sua importância, a discussão sobre o SIMCE será tratada mais adiante neste texto.

\section{O pacto educacional: um avanço democrático ou um processo de gattopardismo?}

De toda forma, com os parâmetros resumidos antes e com as omissões destacadas, finalmente, em 12 de novembro de 2007, a mídia chilena colocou novamente em grande destaque o tema da educação, agora com ênfase na importância do pacto educacional assinado

\footnotetext{
9 Em 2007, o valor do repasse do governo central aos mu-
} nicípios foi de 33 mil pesos mensais por aluno presente em aula o que representava aproximadamente $\mathrm{R} \$ 132,00$. Com esse aporte, as escolas devem arcar com todas as despesas de manutenção e funcionamento, inclusive pagamento de salários dos docentes. 
naquela data entre o governo, sua base de apoio legislativo (a Concertación) e a oposição agrupada no bloco Alianza. Fica a dúvida: as imagens triunfantes de representantes de todo o espectro político chileno, de braços erguidos e mãos dadas, divulgadas em todos os órgãos de comunicação impressos e televisivos do país, representariam realmente um avanço democrático ou, como diversas vozes críticas classificaram na ocasião, simbolizariam apenas aquele conhecido processo de gattopardismo, ilustrado na saga histórica de Lampedusa, quando tudo muda para que nada realmente atinja o status quo?

Este estudo não teve a pretensão de responder a essa complexa questão; no entanto, poderá dar subsídios para melhor compreensão e acompanhamento dos resultados das inovações encaminhadas, traçando um painel abrangente do atual debate educacional chileno.

\section{A pesquisa}

Para consecução do objetivo explicitado, os procedimentos da pesquisa incluíram levantamento documental junto ao Observatório de Políticas Educacionais da Universidade do Chile (OPECH), ao Programa de Promoción de la Reforma Educativa em América Latina y el Caribe (PREAL) e ao MINEDUC, bem como entrevistas realizadas com diversos agentes do atual processo de mudança política, como: líder do movimento estudantil, assessora do sindicato docente (Colégio de Professores), especialista do MINEDUC, pesquisadores das políticas educacionais vinculados a universidades, à Organização das Nações Unidas para a Educação, a Ciência e a Cultura (UNESCO)/ Oficina Regional de Educación para América Latina y el Caribe (OREALC) e ao PREAL e diretores de escolas que puniram com expulsão alunos participantes da "revolta". O estudo da bibliografia pertinente incluiu autores que anteciparam o debate sobre a necessidade da "reforma da reforma" e aqueles que vêm discutindo desde 2006 o movimento estudantil, o primeiro projeto da LGE, o pacto educativo e suas repercussões.
Adicionalmente, em vista da coincidência entre o período do trabalho de campo e a assinatura do acordo entre o governo e a oposição - fato que gerou acalorada polêmica pública entre representantes de diferentes setores acadêmicos, políticos e econômicos -, foi necessária uma extensa pesquisa do material publicado pela imprensa, de modo que captasse o choque mais imediato entre interesses e valores envolvidos e as nuanças mais atuais do debate educacional chileno. Assim, entrevistas concedidas por líderes de diversos setores e artigos produzidos por especialistas e publicados em jornais nas semanas que antecederam a assinatura do pacto e nas subseqüentes foram considerados subsídios importantes para este estudo.

Os dados provenientes das fontes consultadas permitem que se esboce um desenho do atual debate sobre o papel do movimento estudantil, sobre o recente pacto educativo e sobre outros aspectos da política educacional chilena. Em seguida, focalizo esse debate, arrolando os argumentos pró e contra cada tema considerado.

\section{As diferentes avaliações sobre as concessões e omissões do pacto educativo}

O pacto estabelecido satisfez bastante os agentes que defendiam o financiamento público dos estabelecimentos privados, a legitimidade da pré-seleção de alunos, a participação das famílias no financiamento das escolas particulares subvencionadas e a legitimidade do lucro dos proprietários desses estabelecimentos; ou seja, o consenso obtido entre governo e oposição atendeu melhor aos interlocutores e analistas situados mais à direita do espectro político chileno. De fato, embora, como já visto, alguns limites tenham sido impostos, ficaram preservados os princípios das leis de mercado na educação, o que agradou aos setores conservadores. Por exemplo: Cristián Larroulet, presidente da organização Liberdad y Desarrollo - um centro nãogovernamental de estudos de políticas conhecido pela defesa da liberdade econômica, do Estado mínimo e da iniciativa privada -, em entrevista a destacado jornal de Santiago, louvou os aspectos do pacto que fortalecem 
a escola particular e o controle de qualidade por meio de agência autônoma. Em suas palavras:

É um importante acordo em que se trabalhou muito seriamente. Avançou-se na consolidação e na defesa de coisas importantes, como a provisão privada de educação e o tema da garantia de qualidade, com instrumentos que serão efetivos e eficientes. (El Mercurio, 15 nov. 2007, p. C3, tradução livre)

O presidente da Corporación Nacional de Colégios Privados, Rodrigo Bosch, também elogiou o acordo no que diz respeito à consolidação do empreendimento privado em educação (El Mercurio, 18 nov. 2007, p. A29) e o presidente da Federación de Instituciones de Educación Particular, Jesús Triguero, segue a mesma linha, defendendo, porém, aprofundamento das leis de mercado na educação, com mudanças no estatuto docente, de forma que permitisse a demissão imediata de professores de mau desempenho e de concessão de prêmios aos melhores profissionais ( $E l$ Mercurio, 15 nov. 2007, p. C9). ${ }^{10}$

José Joaquín Brunner, influente personalidade no mundo acadêmico e político, classificou o acordo como "transcendental", temendo por sua nãoconcretização, principalmente por possível excesso de burocracia (Brunner, 2007a). Esse mesmo autor já havia defendido, com antecipação, a criação de uma agência autônoma de controle de qualidade, "que não se considerasse integrante da administração orgânica do Estado e à qual não se aplicassem as regras gerais ou especiais do setor público, mas cujo pessoal fosse regido pelas normas do setor privado" (Brunner, 2007b, p. 158, tradução livre). Como já foi explicitado, essa foi a proposta dos partidos de oposição incorporada ao acordo. Brunner também já havia criticado o primeiro projeto da LGE no que diz respeito à proibição de qualquer tipo de seleção de candidatos à matrícula até a $8^{\mathrm{a}}$ série do ensino fundamental, argumentando

${ }^{10}$ É de notar-se que a exigência explicitada diz respeito aos docentes da rede municipal, uma vez que os professores do sistema privado subvencionado já estão sujeitos a essas regras. que a "seleção acadêmica é um dispositivo legítimo de política escolar" e que "seus benefícios e custos dependem da forma como é aplicada" (Brunner, 2007c, p. 245). Como mencionado, o acordo assinado passou a admitir a pré-seleção de alunos a partir da $6^{\mathrm{a}}$ série do ensino fundamental, por pressão principalmente dos representantes de escolas privadas subvencionadas e dos partidos da Alianza.

Outros analistas consultados consideram o pacto um avanço em relação à profunda segmentação educacional existente e aos diversos tipos de abuso por parte de muitas escolas privadas subvencionadas. Têm, todavia, críticas a alguns fundamentos do modelo, argumentando que uma educação realmente igualitária exige que se avance na construção de novos consensos, o que apenas será possível por meio de embates políticos e sociais democráticos. Essa foi, por exemplo, a posição do presidente do Conselho Assessor Presidencial, Juan Eduardo Garcia-Huidobro, entrevistado para a pesquisa. Admitindo a legitimidade do lucro dos empresários, "desde que tal lucro represente apenas a possibilidade de viver honestamente do fruto de seu trabalho", Garcia-Huidobro mostrou-se satisfeito com o fato de que o acordo aceitou a evidência de que as leis de mercado não são suficientes para regular a educação e que se passasse a reconhecer explicitamente o papel essencial do Estado para a garantia da qualidade e de outros padrões normativos. Todavia, é enfático ao criticar o "financiamento compartido" e a pré-seleção de alunos em qualquer nível.

A contribuição dos pais no financiamento será sempre um fator de desequilíbrio do sistema, comprometendo irremediavelmente a igualdade de oportunidades. A educação privada tem avançado muito em vista da possibilidade de receber subsídios oficiais e ainda cobrar mensalidades das famílias. Sem esse recurso, a rede privada subvencionada diminuiria bastante, voltando o Estado a ser o principal provedor da educação [...] A pré-seleção de alunos, em qualquer nível, por qualquer motivo, mesmo acadêmicos, não é aceitável, principalmente porque em nosso país o desempenho está muito atrelado ao nível socioeconômico dos alunos. (Transcrição e tradução livres) 
Em sua crítica à seletividade, os argumentos de Garcia-Huidobro coincidem com outras análises. Por exemplo, Carlos Peña González, conhecido especialista e professor da Universidade Diego Portales, assim se posiciona sobre o tema:

Se o sistema escolar fosse mais igualitário em seus recursos, ou seja, se as oportunidades de aprendizagem estivessem repartidas com eqüidade no conjunto das escolas, este problema não se colocaria com a urgência que se coloca hoje no Chile. Sua urgência deriva do fato de que, quando discutimos a seleção em nosso país, estamos discutindo como (ou com base em que critérios) distribuiremos as oportunidades de êxito escolar. Falar de seleção no Chile (diferentemente de outros países e, por isso, a comparação não é fácil) não tem a ver com a proteção de projetos educativos diversos ou com a promoção do mérito, mas, sim com a outorga de oportunidades escolares de qualidade, que são escassas [...] Deve-se levar em conta que o sistema escolar tem vínculos quase indissolúveis com a democracia e com a coesão social e que esses vínculos exigem medidas que favoreçam a escola a ser um lugar de encontro e de reconhecimento, em vez de um espaço de diferenciação ou de uniformidade. (Peña González, 2007, p. 247-250, tradução livre)

O diretor da área de currículo e avaliação do MINEDUC e um dos principais representantes do governo na negociação com a oposição, Pedro Montt também entrevistado na pesquisa -, foi bastante assertivo em destacar a importância do pacto, embora reconhecendo que há muito ainda a avançar.

Trata-se de um processo histórico e gradual. Há um ano, o consenso conseguido agora não seria sequer imaginável. Mas caminhamos, embora haja muito ainda a ser feito. O importante é que os colégios deste país agora serão obrigados a prestar contas e a garantir a qualidade do ensino oferecido. (Transcrição e tradução livres)

Opiniões mais críticas foram registradas. Por exemplo, o professor Alfredo Rojas Figueroa, que falou à pesquisa apenas em seu nome e não como oficial de programas da UNESCO/OREALC que é, opina que o pacto é somente uma acomodação de interesses das elites, uma vez que ainda são permitidos o lucro dos empresários que recebem subsídios públicos e a contribuição dos pais no financiamento. O sistema educacional continuaria, assim, a reproduzir a profunda segmentação da sociedade chilena. Ele afirma ainda que não há esperança de que o Estado volte a cumprir seu papel de "Estado docente", pois as leis de mercado na educação "chegaram para ficar". Nesse sentido, concorda com diversas análises feitas por pesquisadores do OPECH, que, conforme já mencionamos, identificam o recente pacto educativo com um processo de gattopardismo, em que tudo muda para que nada de substantivo se altere (OPECH, 2007a).

Essa posição é a mesma de uma importante líder estudantil ouvida para este estudo. ${ }^{11}$ Aluna de um dos colégios públicos de excelência (ou "paradigmáticos"), foi obrigada a mudar de escola, depois de sua participação na mobilização dos "pingüins". A entrevistada acusou o pacto de ignorar reivindicações nodais do movimento estudantil, como a reformulação da JEC, a melhoria das condições de trabalho docente (número de alunos por classe) e a eliminação do lucro dos empresários.

A destacada assessora da presidência do sindicato docente, Jenny Assael, foi outra voz crítica registrada pela pesquisa. Lamenta o recuo representado pelo acordo em relação ao projeto inicial da LGE, o qual, como já vimos, foi apresentado pela presidenta $\mathrm{Ba}$ chelet em abril de 2007 ao Congresso e rejeitado. Na opinião dessa interlocutora, aquele primeiro projeto estava bem negociado e avançava muito em direção à democratização do sistema ao proibir o lucro dos empresários e a pré-seleção de alunos até a $8^{\mathrm{a}}$ série do ensino fundamental. Em suas palavras:

Mesmo sendo ainda tímido, pois não propunha o retorno à centralização da gestão (pleito antigo do sindicato docente) ou o fim da contribuição das famílias no financiamento, o

${ }^{11}$ Houve acordo com a entrevistada de que seu nome não seria publicado. 
projeto inicial do Executivo não passou [...]. O acordo assinado representa um grande retrocesso em relação à proposta inicial da LGE. (Transcrição e tradução livres)

Os analistas que criticam o pacto por deixar intocado o financiamento público da rede particular lembram que as escolas municipais se têm saído melhor que as privadas subvencionadas no atendimento das camadas mais pobres da população. Redondo (2007), por exemplo, chama atenção para os resultados do SIMCE de 2006, os quais evidenciam que os estudantes de famílias de baixa renda obtêm melhor pontuação, em linguagem, matemática e compreensão do meio nas escolas públicas. Os números estão no Quadro 1.

Quadro 1: Média do $4^{\circ}$ ano do ensino fundamental em 2006 por grupo socioeconômico e disciplina

\begin{tabular}{|c|c|c|c|c|c|c|c|c|c|}
\hline \multirow{2}{*}{$\begin{array}{l}\text { Grupo } \\
\text { Socio- } \\
\text { econô- } \\
\text { mico }\end{array}$} & \multicolumn{3}{|c|}{ Linguagem } & \multicolumn{3}{|c|}{ Matemática } & \multicolumn{3}{|c|}{$\begin{array}{c}\text { Compreensão } \\
\text { do meio }\end{array}$} \\
\hline & MUN & PSUB & PPAG & MUN & PSUB & PPAG & MUN & PSUB & PPAC \\
\hline \multirow{2}{*}{ Baixo } & $(+)$ & & & $(+)$ & & & $(+)$ & & \\
\hline & 238 & 227 & - & 224 & 206 & - & 232 & 220 & - \\
\hline \multirow{2}{*}{$\begin{array}{l}\text { Médio } \\
\text { baixo }\end{array}$} & & & & & & & & & \\
\hline & 235 & 235 & - & 227 & 227 & - & 236 & 236 & - \\
\hline \multirow{2}{*}{ Médio } & & $(+)$ & & & $(+)$ & & & $(+)$ & \\
\hline & 248 & 256 & - & 243 & 252 & - & 253 & 263 & - \\
\hline \multirow{2}{*}{$\begin{array}{l}\text { Médio } \\
\text { alto } \\
\end{array}$} & & & & & & & & & \\
\hline & 271 & 275 & - & 268 & 272 & - & 280 & 284 & - \\
\hline \multirow{2}{*}{ Alto } & & & $(+)$ & & & $(+)$ & & & $(+)$ \\
\hline & - & 289 & 298 & - & 288 & 298 & - & 297 & 306 \\
\hline \multirow{2}{*}{$\begin{array}{l}\text { Média } \\
\text { total }\end{array}$} & & & & & & & & & \\
\hline & 241 & 260 & 297 & 234 & 255 & 297 & 243 & 266 & 305 \\
\hline
\end{tabular}

MUN: Estabelecimentos municipais.

PSUB: Estabelecimentos particulares subvencionados.

PPAG: Estabelecimentos particulares pagos (sem subsídio do governo).

(+): Indica a dependência administrativa que obtém pontuação significativamente mais alta que as outras dependências administrativas.

(-): Indica que a categoria não tem estudantes ou que tem menos de $0,5 \%$ do total.

Nota: A média total foi calculada sobre a base de todos os estudantes de cada dependência administrativa e grupo socioeconômico, incluindo alunos e alunas de categorias com menos de $0,5 \%$ do total de estudantes. Por esse motivo, a média dos estabelecimentos particulares pagos pode parecer inconsistente com a média do grupo socioeconômico alto.

Fonte: Redondo (2007).
As concessões e omissões do pacto também foram criticadas pelo pesquisador do OPECH, Juan González López. ${ }^{12}$ A legitimação do lucro dos proprietários de escolas subvencionadas foi considerada por esse estudioso um retrocesso gravíssimo em relação ao primeiro projeto da LGE, uma vez que, com o acordo, teria ficado clara a opção de não fortalecer a escola pública, na qual se educam os setores mais pobres do país. González López traz um exemplo muito elucidativo do grau de mercantilização da educação chilena: a partir de 1997, quando houve aumento substancial do financiamento estatal para matrículas de alunos com problemas de aprendizagem, tais matrículas tiveram incremento desmesurado (195,8\% entre 1997 e 2005). $\mathrm{O}$ pesquisador pergunta:

O que é isto? Uma epidemia de atraso mental no Chile? Quem faz o diagnóstico? É casualidade que a maioria dos proprietários das escolas especiais ou diferenciadas surgidas nos últimos tempos sejam fonoaudiógas ou psicopedagogas? Que do total da matrícula especial a maioria seja de "distúrbio de linguagem" (patologia de fácil diagnóstico) [ou diagnosticadas precisamente por fonoaudiólogos ou psicopedagogos] e que esta se concentre nos estabelecimentos particulares subvencionados? (González López, 2007a, p. 8, tradução livre)

O projeto da Lei da Subvenção Preferencial, elaborado pelo Executivo antes da movimentação estudantil, pois já fazia parte do programa inicial do Governo Bachelet, pretendeu diminuir as desvantagens das escolas municipais que abrigam as populações mais desfavorecidas, além de despertar $o$ interesse da iniciativa privada para o atendimento desses setores. O projeto concede aumento na subvenção por aluno pobre matriculado. Além disso, o estabelecimento que tiver maior número de estudantes nessas condições receberá percentual extra

${ }^{12} \mathrm{O}$ professor González López foi o principal interlocutor para este trabalho, tendo avalizado o projeto inicial, o que possibilitou a obtenção do financiamento da FAPESP. 
do financiamento. Nas avaliações de sistema (prova SIMCE), as escolas que receberem financiamento diferenciado deverão mostrar melhoria do rendimento dos alunos, sob pena de perder o benefício. A expectativa é de que, na esteira do acordo, a Lei da Subvenção Preferencial, já aprovada no Senado, seja facilmente aceita pelos deputados.

No entanto, essa legislação já sofre grandes restrições por parte de diversos analistas. Garcia-Huidobro e Bellei, por exemplo, tecem críticas bem fundamentadas a esse projeto, questionando a pretensão dessa iniciativa de corrigir as históricas iniqüidades do sistema. Entre outros argumentos, os autores negam a validade de sanções e incentivos correspondentes à produtividade da escola, uma vez que

[...] existem conhecidos problemas com a medição dos resultados da aprendizagem [Sistema SIMCE] que desaconselham seu uso como critério de produtividade das escolas. Os erros de método podem fazer variar muito os resultados de uma escola ao longo dos anos, sem que isso esteja associado a melhorias ou deteriorações reais da qualidade do ensino [...]. Além de sua limitada validade, tampouco está clara a efetividade educativa da teoria do prêmio/castigo. A experiência chilena de livre competição tem sido exemplar a esse respeito: ainda que as escolas compitam ativamente no mercado do prestígio escolar, os resultados da aprendizagem dos alunos não melhoram. Adicionalmente, as escolas perdedoras iniciam penosos processos deterioração institucional, social e acadêmica. Em outras palavras, o mercado pode criar um sistema escolar altamente dinâmico, mas não por isso de melhor qualidade. (Garcia-Huidobro \& Bellei, 2006, p. 103-107, tradução livre)

A reivindicação dos estudantes de revisão ou extinção da JEC é outra omissão do acordo. À primeira vista, a um observador externo, causa estranheza o questionamento dos jovens a respeito de tal item da política educacional chilena, o qual, introduzido a partir de 2000, foi consensualmente considerado um enorme avanço na direção da construção da qualidade do ensino. Entretanto, os depoimentos registrados pela pesquisa deixaram claros os motivos dos estudantes ao rejeitarem a JEC. Juan Gonzáles López, pesquisador do OPECH que tem acompanhado muito de perto o movimento estudantil, foi muito didático ao expor o tema:
A Jornada Escolar Completa transformou-se em um pe- sadelo para os estudantes, porque em todas as escolas não há atividades diferenciadas. Trata-se de "mais do mesmo", uma vez que se tratou de apenas reforçar os conteúdos cobrados pelo SIMCE. Os dois períodos na escola tornaram-se pesa- dos, monótonos e desinteressantes. Além disso, há a questão da merenda, que é pouca. Os estudantes chamam a JEC de “jornada da fome”. (Transcrição e tradução livres)

A líder estudantil entrevistada externou as mesmas críticas à JEC, acrescentando que, em sua opinião, os colégios não têm infra-estrutura para abrigar os alunos por dois períodos completos, o que torna insuportável o longo tempo diário em sala de aula. Quanto à merenda, a jovem informou o seguinte: uma vez que, em qualquer escola, apenas os alunos comprovadamente pobres a recebem, esse benefício acaba tornando-se um estigma; muitos se recusam a comer o lanche oferecido para não serem conhecidos como necessitados.

A pesquisa da Direção de Estudos Sociológicos da Pontifícia Universidade Católica do Chile (PUCChile, 2005) vem ao encontro dos depoimentos registrados por este estudo. Sobre as refeições, o relatório da universidade conclui, entre outros pontos, que:

$12 \%$ dos alunos do ensino médio e $4,6 \%$ de alunos do ensino fundamental assinalam "não almoçar", o que, traduzido em número de alunos, são cifras preocupantes, em especial se considerarmos as extensas jornadas que implica a JEC. (p. 135, tradução livre)

O estudo da PUC-Chile traz outros dados que confirmam a validade da crítica dos estudantes à omissão do pacto quanto à JEC, que parece ter deixado de cumprir o objetivo de estender a aprendizagem dos alunos para além das disciplinas "duras". Ou, em outras palavras, o aumento da carga horária não significou, 
em muitas escolas, a inclusão de atividades diversificadas, mas apenas o reforço de conteúdos visados pela prova SIMCE. Nos termos da pesquisa:

Existe uma alta concentração de horas de plano de estudos em quatro principais setores: linguagem e comunicação, matemáticas, história/ciências sociais e ciências (biologia, física e química) [...]. Há porcentagens significativas de estabelecimentos que realizam mais horas semanais do que as definidas pela norma, nas áreas de linguagem e comunicação, matemáticas e ciências [...]. (PUC-Chile, 2005, p. 131, tradução livre)

Outro item não incluído no pacto, como já vimos, foi a desmunicipalização da gestão educacional. Todavia, só o aceno do governo nessa direção já provoca grande polêmica. Ou seja, o sindicato docente e outros agentes mais à esquerda do espectro político chileno sempre foram favoráveis ao retorno da centralização da gestão educacional no nível do governo nacional. Qualquer política de desmunicipalização que não siga essa direção (tal como as propostas governamentais de regionalização da gestão ou de criação de outra unidade geográfica/administrativa) não satisfará integralmente esses setores. Além disso, os alcaides dos municípios mais ricos já iniciaram protestos contra qualquer tipo de desmunicipalização ${ }^{13}$ e um representante dos partidos da Alianza declarou que o bloco não discutirá qualquer projeto que vise alterar a descentralização municipalizada (La Tercera, 14 nov. 2007, p. 14).

Quanto ao estatuto docente, também não mencionado pelo acordo, é preciso enfatizar que o confronto político é especialmente duro em relação a esse tema, tendo os professores que ceder em alguns aspectos para manter ainda intocada sua estabilidade funcional e a base salarial nacional. Foi nesse embate que se deu a negociação que introduziu, a partir de 2003, a avaliação periódica dos docentes das escolas municipais.

${ }^{13}$ Matéria do jornal La Tercera, de 22 de novembro de 2007, p. 17, traz depoimento do presidente da Associação de Municípios nesse sentido.
Tal sistema avaliativo é bastante complexo e compreende duas modalidades: a obrigatória e a voluntária. A avaliação obrigatória não inclui conhecimentos específicos da disciplina nem aspectos funcionais (como faltas e atrasos), apenas prática pedagógica; a essa avaliação devem submeter-se, a cada quatro anos, todos os professores municipais. Ela compreende três partes: avaliação de uma aula filmada; avaliação de um portfólio organizado pelo professor; e auto-avaliação e avaliação pelo diretor e por pares. Os professores que não alcançarem bons resultados nesse processo podem ser indicados para fazer um curso de aperfeiçoamento ou podem ser afastados e só voltar à escola depois de uma reciclagem mais profunda. Os profissionais que atingirem o nível "destacado" ou "competente" devem requerer o adicional de salário, válido por quatro anos, que atinge 87 mil pesos mensais (aproximadamente $\mathrm{R} \$ 350,00)$. Em todas as avaliações até agora, mais de 95\% dos docentes atingem resultado favorável.

A avaliação voluntária é mais rigorosa e, além da parte pedagógica, cobra também conhecimentos específicos das disciplinas. Entretanto, são poucos os docentes que se submetem a esse processo, uma vez que as vantagens salariais são pequenas e válidas por apenas dois anos, devendo o professor ao fim desse tempo submeter-se a novas provas se quiser continuar recebendo o bônus correspondente.

A adesão do sindicato dos professores ao sistema avaliativo não foi suficiente, todavia, para amenizar as críticas de vários setores ao estatuto docente. A pesquisa registrou diversos exemplos dessa crítica. Já vimos que Jesús Triguero, presidente da Federación de Instituciones de Educación Particular, sugeriu a adoção de norma que possibilitasse a demissão de docentes com mau desempenho. Soledad Arellano, professora de Economia da Universidade do Chile, em entrevista a um jornal, também criticou a omissão do acordo quanto a esse aspecto das políticas educacionais, argumentando que o estatuto introduz "rigidez na administração dos estabelecimentos, limitando a possibilidade de despedir os professores que não se desempenham bem" (El Mercurio, 18 nov. 2007, p. A29, tradução livre). 
Mesmo entre profissionais de escolas municipais, parece haver vozes favoráveis a instrumentos de demissão de professores com má atuação. Foi essa, por exemplo, a opinião de diretor de um liceu municipal ouvido para este estudo:

As escolas privadas têm a vantagem de ter liberdade de gestão. Elas podem demitir os professores que não cumprem os objetivos propostos. Nós, das escolas municipais, sofremos muito na gestão recursos humanos [...]. Há sempre professores que têm desempenho abaixo das exigências mínimas da profissão e eles devem continuar conosco, o que prejudica todo o resultado da escola. (Transcrição e tradução livres)

A necessidade de flexibilização do estatuto docente tem o apoio até mesmo de alguns críticos da introdução de leis do mercado na educação. Tais analistas, entretanto, recusam o "tratamento de choque" proposto pelos defensores do mercado como regulador da educação, sugerindo uma abordagem formativa da avaliação. A posição do professor Rojas Figueroa é paradigmática nesse sentido. Diz ele:

Mesmo os professores e professoras de bom nível pedagógico, bom humor, criativos etc. requerem o juízo crítico de outros para melhorar. Mas requerem um juízo crítico amistoso, orientado a apoiar o crescimento. Em termos de políticas, os mesmos recursos que hoje se utilizam para fazer as provas do SIMCE poderiam ser utilizados para financiar avaliações e acompanhamentos ad hoc realizados por universidades ou consultores [...], [com tal tipo de avaliação e acompanhamento] seria possível produzir suficiente evidência para demonstrar a necessidade de se prescindir dos serviços de docentes que definitivamente se equivocaram de profissão (pois esses tipos existem) e, por fim, flexibilizar o Estatuto Docente para facilitar a saída [daqueles docentes] das escolas. (Rojas Figueroa, 2005, p. 4, tradução livre)

Nesse clima, será importante acompanhar se (ou até quando) os professores resistirão às investidas favoráveis a mudanças radicais em seu estatuto.

\section{As diferentes avaliações sobre a "Revolta dos Pingüins"}

A pesquisa nas edições dos jornais de meados de 2006, quando a mobilização estudantil atingia seu ápice, indica que os mais variados setores sociais se sentiram obrigados a manifestar-se sobre o evento. Editoriais, cartas de leitores, artigos de especialistas multiplicaram-se naqueles dias, com declarações a favor e contra o movimento. As avaliações contrárias em geral condenavam os estudantes pela forma ostensiva de seus protestos, exigindo respeito à "ordem". Muitos críticos se ressentiam da censura dos "pingüins" ao sistema privado subvencionado. O editorial do prestigiado jornal El Mercurio de 1 de junho de 2006 é um exemplo da defesa da liberdade da iniciativa privada na educação e de velada crítica à mobilização dos estudantes.

No entanto, logo após a assinatura do pacto, a ministra da Educação, Yasna Provoste, em declaração aos jornais, fez questão de ressaltar o papel essencial do movimento estudantil no resultado alcançado, reputado por ela como "histórico" e "notável" ( $\mathrm{La}$ Tercera, 14 nov. 2007, p. C3).

A maior parte dos analistas entrevistados para a pesquisa também valorizou a iniciativa dos "pingüins". O professor Garcia-Huidobro ressaltou que, desde 2005, os estudantes secundaristas de Santiago se vinham reunindo para levantar a pauta de reivindicações e que as discussões levaram a um amadurecimento político dos jovens. Essa também foi a opinião dos especialistas González López, do OPECH, e de Rojas Figueroa, da UNESCO/OREALC.

Outros interlocutores, no entanto, fizeram referências críticas à mobilização estudantil, minimizando seu papel no conjunto das mudanças políticas. A diretora do PREAL, Marcela Gajardo, expressou-se assim sobre o assunto:

A mobilização dos "pingüins" foi manipulada politicamente e não conseguiu impor suas principais reivindicações. Houve enfraquecimento do movimento e muitas divisões 
internas. As tentativas de rearticulação, em 2007, fracassaram totalmente. (Transcrição e tradução livres)

Também ouvido pela pesquisa, um diretor de liceu municipal, tradicional, que tomou medidas drásticas contra alguns dos participantes do movimento, fez outras restrições à mobilização:

No começo nós apoiamos o movimento. Eles vieram dizer que deviam “tomar” a escola, pois, do contrário, seriam mal vistos por colegas de outros liceus. Nós entramos em acordo e no princípio tudo foi muito organizado. A escola parou e os alunos faziam plantão para zelar pelo patrimônio. Mas depois de dois dias tudo mudou. Havia desordem, bebidas e drogas. A escola foi danificada. Sofremos uma ação judicial. Perdemos em um primeiro momento, mas em um segundo julgamento a escola ganhou a ação e pôde impor sanções aos líderes [...] Não houve expulsão, mas eles foram transferidos para outras escolas. (Transcrição e tradução livres)

Em seu depoimento para a pesquisa, o dirigente de uma escola católica subvencionada que puniu com expulsão os líderes do movimento justificou as medidas tomadas da seguinte forma:

Foi uma minoria de alunos que invadiu a escola e tentou paralisar as atividades. Mas isso aconteceu só em uma parte da escola. Em outras [áreas] as aulas continuaram. Houve depredação e prejuízo quanto ao recebimento da subvenção oficial [...]. Esses alunos não podiam continuar na escola, pois infligiram o regulamento interno que haviam concordado em seguir, quando optaram pela escola [...]. Entraram com ação judicial e, no primeiro momento, ganharam, mas houve recurso e eles acabaram perdendo. A escola baseou-se em seu regulamento interno e a justiça acabou reconhecendo esse direito. (Transcrição e tradução livres)

A líder estudantil entrevistada admitiu a divisão do movimento, uma vez que havia muitos interesses envolvidos. De fato, os alunos dos liceus municipais paradigmáticos (de excelência), ao contrário de seus colegas matriculados em escolas sem prestígio, eram favoráveis à pré-seleção dos candidatos. Outros líderes reivindicavam que o estatuto docente deveria ser revisto, de forma que tornasse a carreira dos professores mais permeável às leis de mercado, com o que não concordavam outras lideranças mais alinhadas com uma concepção de "Estado docente". Todavia, o que, na opinião de nossa entrevistada, realmente enfraqueceu a mobilização foi a aprovação, em junho de 2007, da nova legislação de penalidade de jovens e adolescentes, que admite penas até de prisão para maiores de 14 anos:

Foi muita coincidência essa lei, que estava em tramitação há muitos anos, ser aprovada quando nos mobilizamos. Isso assustou os jovens e suas famílias, porque houve colegas meus que já foram enquadrados nessa lei e hoje prestam serviços comunitários, mas podiam estar presos. (Transcrição e tradução livres) $)^{14}$

Mais adiante, na conclusão deste texto, aponto desdobramentos do movimento estudantil chileno em 2008. São notícias que parecem confirmar a análise de nossa entrevistada quanto ao novo e desmesurado rigor da repressão oficial, mas que também indicam o continuado vigor da "Revolta dos Pingüins".

\section{As controvérsias sobre o SIMCE e as repercussões dos resultados da prova PISA}

A reflexão do professor Rojas Figueroa sobre o SIMCE aqui referida (Rojas Figueroa, 2005) é apenas uma das múltiplas facetas da polêmica que se constrói em torno desse instrumento de avaliação da qualidade das escolas e do sistema. Em contrapartida, também já vimos neste texto como os resultados do SIMCE têm sido usados (Quadro 1) pelos defensores da educação estatal para demonstrar que o sistema municipal atende

${ }^{14}$ A lei que diminuiu a maioridade penal tem sido criticada por muitos especialistas, que vêm na legislação apenas mais um instrumento de aprofundamento da segmentação social chilena, já que os condenados seriam apenas os filhos de famílias de baixa renda. A esse respeito, ver Sobarzo (2007). 
melhor às camadas mais pobres da população. Nesse último caso não são consideradas as críticas (como as de Garcia-Huidobro e Bellei, 2006, aqui mencionadas) que apontam falhas no método que enfraqueceriam a validade do instrumento.

Na verdade, a cada publicação dos resultados do SIMCE trava-se no Chile intensa discussão nos meios acadêmicos e na mídia sobre qual seria sua correta interpretação. Os resultados de 2003, por exemplo, suscitaram profunda polêmica entre o sindicato docente e os agentes oficiais, uma vez que o porta-voz do MINEDUC responsabilizou publicamente os professores pelos maus resultados, acusando-os de precário domínio do conteúdo das disciplinas. Em sua resposta, o sindicato contrapôs os bons níveis atingidos pela absoluta maioria dos docentes no processo avaliativo a que se submeteram naquele ano, quando $96 \%$ dos profissionais alcançaram os níveis de desempenho esperados. Para a entidade docente, a responsabilidade seria principalmente das políticas governamentais e da perversa segmentação da sociedade chilena (Colegio de Profesores, 2004).

Um documento mais recente do Observatório das Políticas Educacionais (OPECH, 2007b) faz uma análise bastante profunda da origem do SIMCE e de seu uso. A crítica não nega que esse instrumento seja um indicador necessário, mas reivindica que não seja o único para medir a qualidade da educação. Algumas das principais restrições ao sistema de avaliação são as seguintes:

a) Não faz sentido comparar resultados de escolas que funcionam em condições totalmente distintas, com diferenças de até dez vezes o nível de gasto por aluno e que recebem estudantes de status socioeconômico e capital cultural muito distintos. Na opinião dos analistas, o mais correto seria comparar cada escola com ela mesma, medindo o "valor agregado" a cada período.

b) O foco do SIMCE na avaliação de matérias "duras" tem empobrecido todo o processo, pois as escolas tratam de apenas reforçar o adestramento em linguagem e matemáticas, não dedicando tempo suficiente para outras aprendizagens.

c) Um dos objetivos do SIMCE - aquele de guiar os pais na escolha da escola para seus filhos - é contestado por dados de pesquisa que indicam que as famílias pobres optam por escolas mais próximas de suas residências, por aquelas cujos professores são mais afetuosos e saibam manter a disciplina, aquela onde a merenda pareça melhor ou onde seus filhos estejam mais protegidos da violência. No processo de escolha, os pais não levam em conta a classificação do estabelecimento no ranking construído a partir dos resultados da avaliação do sistema.

d) A principal função do SIMCE - orientar as escolas na direção de melhoria de seu trabalho - não tem sido cumprida, pois, se forem consideradas apenas as médias dos três níveis avaliados ( $4^{\mathrm{a}} \mathrm{e} 8^{\mathrm{a}}$ séries do ensino fundamental e $2^{\mathrm{a}}$ série do ensino médio), constata-se que não houve, desde a década passada, qualquer aumento significativo da pontuação em qualquer dos três sistemas de administração educacional (municipal, privada e privada subvencionada). Segundo os analistas, a conclusão mais consistente sobre os últimos resultados do SIMCE realmente confirma que os filhos das famílias mais pobres obtêm pontuações significativamente mais altas em escolas municipais (idem).

Ao lado da polêmica criada pelos resultados do SIMCE, outra prova padronizada, essa de abrangência internacional, também tende a levantar controvérsias: o PISA. Os últimos resultados dessa avaliação foram divulgados no início de dezembro de 2007 e referiamse à prova realizada em 2005. A reação dos órgãos oficiais foi de comemoração, ante a ótima classificação obtida pelos alunos chilenos, que alcançaram o primeiro lugar em leitura e em ciências e o segundo em matemática, em comparação com estudantes de outros 
países latino-americanos. Pedro Montt, diretor da área de currículo e avaliação do MINEDUC, entrevistado para a pesquisa, assim se expressou:

Finalmente os resultados de 17 anos de trabalho dos governos da Concertación começam a aparecer. A prova focaliza alunos de 15 anos, ou seja aqueles que começaram a cursar o Ensino Básico precisamente quando se iniciava a reforma curricular. São "os filhos da reforma", e agora se sabe que estão bem encaminhados. (Transcrição e tradução livres)

Todavia, há outras reações mais cautelosas sobre os resultados do PISA. De forma até surpreendente, o presidente da Federación de Instituciones de Educación Particular, Jesús Triguero, embora considerando auspiciosos os índices obtidos, faz restrições. ${ }^{15}$

Creio que é prematuro comemorar, pois devemos comprovar se esse sucesso se estabiliza e se mantém no tempo. Não se pode esquecer que da prova PISA participaram somente 5.235 estudantes de nosso país, e só jovens de 15 anos, o que não é uma amostra significativa da população estudantil chilena. (La Tercera, seção Correo, 7 dez. 2007, tradução livre)

Outros críticos vão mais longe. Juan González López, pesquisador da $\mathrm{OPECH}$, declarou que o leve aumento registrado não obscurece o fato de que a brecha entre a pontuação de alunos de setores altos e baixos continua crescendo e que não há verdadeira qualidade com tal segmentação educacional.

Os jornais também registraram a manifestação de representantes de vários setores e diversos deles opinaram que não seria vantagem o Chile compararse com países da América Latina, uma vez que, como economia associada à OCDE, seus parâmetros deveriam ser aqueles de países mais desenvolvidos.

${ }^{15}$ Essa declaração deve ser interpretada no contexto atual de reivindicação de aumento dos subsídios à educação, inclusive por parte dos proprietários de escolas privadas subvencionadas.
$\mathrm{Na}$ verdade, parece que, como todos os dados estatísticos, os resultados das duas provas têm sido usados politicamente, para criticar ou para defender as políticas governamentais. O que fica em aberto, para ser esclarecido por especialistas, são questões referentes à possibilidade de uma interpretação convergente desses testes que explicasse as divergências, uma vez que o SIMCE tem mostrado, ao longo dos anos, baixo aproveitamento dos alunos (Conejo, 2005; Rojas Figueroa, 2005; OPECH, 2007b), enquanto os últimos resultados do PISA colocam os alunos chilenos em destaque na América Latina.

\section{Considerações finais}

Como já comentado, o último ato legislativo do Governo Pinochet - na véspera da entrega do poder aos civis - foi a homologação da LOCE. Com essa norma constitucional, a ditadura procurou tornar irreversível o sistema descentralizado e privatizado da educação, implantado por meio de decretos desde o início da década de 1980. Esse esforço do poder agonizante para preservar o modelo educacional já indica a importância política e ideológica das diretrizes traçadas durante os "anos de chumbo"; também explica por que, no Chile, a educação se vem tornando, nos últimos tempos, um campo bastante exacerbado de luta política.

Uma vez que o ciclo democrático foi inaugurado ainda com forte tutela dos militares, o primeiro governo eleito, que tomou posse em março de 1990, não teve condições políticas para propor imediatamente qualquer alteração no sistema herdado. Entretanto, como bem explica Rojas Figueroa (1997), a resignação inicial logo se transformou em adesão e, a partir de 1993, como foi mencionado aqui, houve até aprofundamento da privatização. Em entrevista que deu à pesquisa, o mesmo autor reafirmou que os especialistas, acadêmicos e técnicos que, com a democratização, chegaram ao MINEDUC depois de anos de oposição à política educacional da ditadura acabaram por aderir totalmente ao modelo descentralizado e privatizado, convencidos que foram pelos argumentos das agências multilaterais. 
Essa reviravolta política e ideológica dos anos de 1990, aliada à grande propaganda do êxito da educação chilena - propaganda promovida pelas entidades internacionais - parece ter "anestesiado", por algum tempo, as vozes mais críticas. Além disso, talvez possa ser aventada a hipótese de que a sociedade chilena, uma vez conquistada a democracia, mas ainda profundamente traumatizada pela extrema violência da ditadura, não reuniu, por vários anos, condições psicossociais para radicalizar qualquer enfrentamento político. Essa acomodação pode explicar a perplexidade que, em um primeiro momento, tomou conta de setores oficiais e da própria sociedade diante da explosiva mobilização estudantil de 2006. Todavia, outros instrumentos de crítica ao modelo educacional vigente estão fortalecendo-se. No Legislativo, há dissidentes dentro da base governista que exigem mais restrições aos empresários da educação, inclusive com a proibição de lucro (El Mercurio, 8 dez. 2007, p. C6). O OPECH, promovendo avaliações, pesquisas, estudos e debates sobre as diretrizes oficiais e os resultados do sistema, é reconhecido cada vez mais como fonte de crítica bem fundamentada ao modelo. Outras vozes influentes, como o professor Garcia-Huidobro, que já participou do MINEDUC, vêm ultimamente levantando fortes restrições a alguns aspectos da política implementada por aquele órgão (Garcia-Huidobro \& Bellei, 2006). O Colégio dos Professores também se mobiliza de várias formas para evitar os avanços da mercantilização da educação. De outra parte, a "Revolta dos Pingüins" parece ter-se constituído em exemplo muito visível de que é possível conquistar o espaço público de forma que a voz da cidadania seja ouvida.

Nesse quadro, o pacto educativo, celebrado entre o governo e a oposição em novembro de 2007, pode ser apenas o começo da construção de outro modelo, mais democrático, menos segmentado e menos mercantilizado, mas que preserve e, principalmente, aperfeiçoe algumas conquistas dos governos democráticos, como a obrigatoriedade escolar até o ensino médio, a avaliação periódica dos docentes e a jornada escolar completa. Vai nessa direção a perspectiva traçada pelo OPECH nos seguintes termos:
A direita e os tecnocratas celebram o fim da discussão que fez tremer a institucionalidade educativa que herdamos do regime militar. Os cidadãos e os movimentos sociais devem demonstrar que se equivocam, que a discussão não está terminada, senão que apenas começa. (OPECH, 2007a, p. 6, tradução livre)

Para a conclusão deste estudo, é oportuno refletir se o atual debate educacional chileno traz algum subsídio para a análise de nossa realidade educacional. Em minha avaliação, a principal preocupação da maioria dos professores e pesquisadores daquele país diz respeito à segmentação educacional, que reproduz a segmentação social. Sobre essa questão, um texto de Garcia-Huidobro é paradigmático. Focalizando a América Latina, mas tendo claramente o Chile como referência, destaca:

\footnotetext{
Necessitamos construir um sistema educativo com muito mais mistura social. Nossas sociedades latino-americanas são profundamente segregadas e desiguais, e nossa educação é seu reflexo; se quisermos avançar em direção a sociedades mais democráticas, é preciso instaurar um sistema educativo de igual qualidade para todos, e também com mais integração social em cada um dos estabelecimentos educacionais. (Garcia-Huidobro, 2007, p. 89, tradução livre)
}

No caso chileno, o ideal de uma escola democrática, inclusiva e "não reprodutiva" está muito presente e constitui claro objetivo de muitos grupos de professores e pesquisadores rigorosos e comprometidos, bem como de militantes muito ativos. Este artigo já estava em fase de revisão final para publicação quando, em 25 de abril de 2008, o jornal Folha de S.Paulo, no caderno Mundo, publicou a seguinte notícia:

Manifestações estudantis em várias cidades chilenas terminaram ontem com 470 presos, segundo a imprensa local. A polícia usou gás lacrimogêneo e canhões d’água para conter os milhares de manifestantes, que marcharam na capital, Santiago, e em outras cidades. Os manifestantes pediam passe livre no transporte e o "fim do lucro no sistema educacional" e protestaram contra o projeto da Lei Geral de 
Educação, enviado ao Congresso pela presidenta Michelle Bachelet. (Folha de S.Paulo, 25 abr. 2008)

Fica evidente, pois, que lá o embate social por melhoria da educação continua vigoroso e que os "pingüins" parecem dispostos a enfrentar os rigores da nova legislação de penalidade juvenil para conseguir o que consideram seus direitos.

Entre nós, embora a luta por melhor qualidade de ensino continue muito viva, trata-se sempre de uma reivindicação "para eles", uma vez que os "nossos" estão bem acomodados em escolas privadas, ainda que de variados níveis de qualidade e variados custos. Em nossa realidade, os resultados de pesquisas que indicam a dramática precariedade da educação básica público não provocam qualquer "revolta", seja de "pingüins" ou de outros setores.

Nós, estudiosos da educação, altamente especializados, bem-intencionados e politizados, continuamos a publicar muitos artigos, a dar aulas em cursos de pós-graduação (cada vez mais numerosos!), a elaborar e orientar muitas teses e a aprová-las todas em bancas rigorosamente selecionadas e muito competentes, a dar assessorias, a freqüentar e organizar incontáveis congressos e seminários nacionais e internacionais (e a desenvolver pesquisas no exterior!).

Nessa ofuscante voragem acadêmica, não mais nos escandalizam (tampouco revoltam os estudantes e suas famílias) os dados, como aqueles de pesquisa recente (uma entre muitas...), indicando que, na rede pública paulista (a mais "rica" do país!), 33,11\% dos alunos chegam à $6^{a}$ série sem saber ler e $28,6 \%$ sem saber escrever; outros 59,44\% lêem, mas não entendem o que está escrito, e $71 \%$ escrevem textos com graves problemas de conteúdo, ortografia, gramática e caligrafia (Fundação Volkswagen, 2007). A avaliação oficial da Secretaria de Educação do Estado de São Paulo, por meio do Sistema de Avaliação do Rendimento Escolar do Estado de São Paulo (SARESP), em sua versão de 2007, mostrou que, em matemática, mais de $80 \%$ dos alunos do ensino fundamental e médio têm índices de aprendizagem abaixo dos mínimos adequados. Em português, os níveis de aprendizagem não satisfatória chegam a $59,8 \%$ na $4^{\mathrm{a}}$ série do ensino fundamental e a $78,8 \%$ na $3^{\text {a }}$ série do ensino médio (SARESP, 2007). Os resultados da prova internacional PISA, que em todas as suas edições têm colocado nossos jovens nos últimos lugares em comparação com todos os participantes, também não chegam a perturbar a rotina da academia, das esferas oficiais e de outros setores envolvidos.

Em contrapartida, parece válido concluir que o atual vigor do debate chileno, rigorosamente focado no questionamento do modelo educacional altamente mercantilizado e segmentado, tem características de vanguarda e, principalmente, de fina sintonia política com a realidade social e educacional do país, o que pode acabar por impor evidências, vencer ou convencer os resistentes, passando a orientar políticas de diminuição das desigualdades.

Quanto a nós, é imperativo indagar se grande parte da nossa tão abundante produção acadêmica está, de fato, pelo menos em última instância, direcionada para atender nosso histórico e irrecusável compromisso de influenciar (ou desencadear) processos de democratização do sistema e de melhoria dos nossos constantes e trágicos índices de aproveitamento escolar.

\section{Referências bibliográficas}

ALMONACID, Claudio. Un cuasi mercado educacional: la escuela privada subvencionada en Chile. Santiago: Universidad Católica de Chile, s.d. Mimeografado.

BEYER, Harald. Una nota sobre financiamiento de la educación. In: BRUNNER, José Joaquín; PEÑA GONZÁLEZ, Carlos (Coords.). La reforma al sistema escolar: aportes para el debate. Santiago: Universidad Diego Portales, 2007.

BRUNNER, José Joaquín. Educación: y ahora, qué hacer? El Mercurio, p. D4, 12 dez. 2006.

. Educación: del acuerdo a la práctica. El Mercurio, p. D4, 14 nov. 2007a.

Aseguramiento de la calidad: pieza clave. In: BRUNNER, José Joaquín; PEÑA GONZÁLEZ, Carlos (Coords.). La reforma al sistema escolar: aportes para el debate. Santiago: Universidad Diego Portales, 2007b.

. Los procesos de selección en los países participantes en PISA 2003. In: BRUNNER, José Joaquín; PEÑA GONZÁLEZ, 
Carlos (Coords.). La reforma al sistema escolar: aportes para el debate. Santiago: Universidad Diego Portales, 2007c.

.; PEÑA GONZÁLEZ, Carlos (Coords.). La reforma

al sistema escolar: aportes para el debate. Santiago: Universidad

Diego Portales, 2007.

CHILE. MINEDUC (Ministério da Educação). Estadísticas de la educación. Santiago: Gobierno de Chile/MINEDUC, 2005.

COLEGIO DE PROFESORES. Declaraciones públicas del Directorio Nacional. Abr. 2004. Disponível em: <www.colegiodeprofesores.cl>. Acesso em: jun. 2004.

CONEJO, Rodrigo. Posición del Observatório de Políticas Educativas respecto a los resultados de la prueba SIMCE cuartos basicos 2005. Santiago: OPECH, 2005.

ERRÁZURIZ, Francisco Javier (cardeal-arcebispo). A nadie puede serle indiferente. El Mercurio, Santiago, p. D1, 6 maio 2007.

FUNDAÇÃO VOLKSWAGEN. Retratos do ensino fundamental: do $6^{\circ}$ ao $8^{\circ}$ ano. 2007. Disponível em: <www.vw.com.br/fundacao. $\mathrm{vw}>$. Acesso em: jan. 2008. (Relatório de pesquisa.)

GARCIA-HUIDOBRO, Juan Eduardo. La expansión educativa en América Latina: nuevos caminos, nuevas exigencias. In: IIPE-UNES$\mathrm{CO} / \mathrm{OEI}$. Informe sobre tendencias sociales y educativas en América Latina. Buenos Aires: IIPE-UNESCO/OEI, 2007. p. 88-89.

.; BELLEI, Cristián. Remédio para la inequidad? La subvención escolar preferencial. Revista Mensaje, Santiago, n. 547, p. 102-105, mar./abr. 2006.

GOBIERNO DE CHILE, ALIANZA Y CONCERTACIÓN. Acuerdo por la Calidad de la Educación: documento técnico. Santiago, nov. 2007. Disponível em: <www.opech.cl>. Acesso em: dez. 2007.

GONZÁLEZ LÓPEZ, Juan. La educación en el liberalismoautoritário: la estrategia biopolítica de la mercantilización. Santiago: OPECH, 2007a. Disponível em: <www.opech.cl>. Acesso em: nov. 2007.

. No estábamos de acuerdo en resguardar el derecho a la educación? Santiago: OPECH, 2007b. Disponível em: <www. opech.cl>. Acesso em: nov. 2007.

INSTITUTO HERBERT LEVY. Ensino fundamental e competitividade empresarial: uma proposta para a ação do governo. São Paulo: s.ed., 1992.

MELLO, Guiomar Namo. Social democracia e educação. São Paulo: Cortez, 1990.

MIZALA, Alejandra. La subvención preferencial. In: BRUNNER, José Joaquín; PEÑA GONZÁLEZ, Carlos (Coords.). La reforma al sistema escolar: aportes para el debate. Santiago: Universidad Diego Portales, 2007.

NUÑES PRIETO, Iván. Conocimiento y decisiones políticas en los origenes de la investigación educativa: Chile, 1917-1957. In: CONGRESO NACIONAL DE INVESTIGACIÓN EDUCATIVA Y INFORMACIÓN, 1., 2000, Santiago. Anais... Santiago, Reduc/ Cide, 2000.

. La tercera, Santiago, Correo, 7 dez. 2007.

OCDE - Organização para a Cooperação e o Desenvolvimento Econômicos. Revision de Políticas Nacionales de Educación. Paris: OCDE, 2004.

OPECH - Observatório de Políticas Educativas de Chile. Universidad de Chile. Un acuerdo que genera desacuerdos. Santiago: OPECH, 2007a. Disponível em: <www.opech.cl>. Acesso em: nov. 2007.

Sistema de medición de la calidad de la educación-

SIMCE: balance crítico y proyecciones imprescindibles. Santiago: OPECH, 2007b. Disponível em: <www.opech.cl>. Acesso em: dez. 2007.

PEÑA GONZÁLEZ, Carlos. Por que no debemos seleccionar. In: BRUNNER, José Joaquín; PEÑA GONZÁLEZ, Carlos (Coords.). La reforma al sistema escolar: aportes para el debate. Santiago: Universidad Diego Portales, 2007.

PUC-CHILE - PONTÍFICIA UNIVERSIDAD CATÓLICA DE CHILE. Dirección de Estudios Sociológicos. Evaluación Jornada Escolar Completa: informe final, Santiago: jun. 2005. Disponível em: <www.opech.cl>. Acesso em: dez. 2007.

REDONDO, Jesús. El fraude de los colegios particulares. Santiago: OPECH, 2007. Disponível em: <www.opech.cl>. Acesso em: out. 2007.

ROJAS FIGUEROA, Alfredo. Da resignação ao consentimento? Privatização da educação básica e média no Chile. Cadernos de Pesquisa, São Paulo: Fundação Carlos Chagas, n. 100, p. 59-78, mar. 1997.

El SIMCE empeora la calidad de la educación y el SIMCE empeora la equidad de la calidad de la educación. Santiago: s.ed., 2005. Disponível em: <http://educacioncalidadyequidad. blospot.com/2005/04/el-simce-empeora-la-calidad-de-la.html>. Acesso em: jan. 2008.

SARESP - Sistema de Avaliação do Rendimento Escolar do Estado de São Paulo. Resultados de 2007. 2007. Disponível em: <saresp. edunet.sp.gov.br/2007>; <www.folha.com.br/080731>. Acesso em: mar. 2007. 
SOBARZO, Mario. Declaración de guerra: los limites éticos de la convivencia moderna. Santiago: OPECH, 2007. Disponível em: <www.opech.cl>. Acesso em: jan. 2008.

TEDESCO, Juan Carlos. Alguns aspectos da privatização da educação na América Latina. Estudos Avançados, São Paulo, v. 5, n. 12, p. 23-44, maio/ago. 1991.

Comentários adicionales. In: PREAL. Quedándonos atrás. Santiago: PREAL, 2001.

ZIBAS, Dagmar M. L. A reforma do ensino médio no Chile: vitrina para a América Latina? Cadernos de Pesquisa, São Paulo: Fundação Carlos Chagas, n. 115, mar. 2002.

DAGMAR M. L. ZIBAS, doutora em educação pela Universidade de São Paulo (USP), foi pesquisadora da Fundação Carlos
Chagas desde 1983, tendo se aposentado em março de 2008. A investigação que deu origem a este artigo, realizada em fins de 2007, foi a última de sua carreira acadêmica. Trabalhos recentemente publicados: "O perverso impasse latino-americano: qualidade da educação x pobreza" (Informe SITEAL 2007, Buenos Aires: IIPE/ UNESCO-OEI, 2007); "Alguns desdobramentos da associação 'público-privado' na administração do ensino técnico no Ceará" (Cadernos de Pesquisa, n. 134, maio/ago. 2008, no prelo); "O ensino técnico a partir da década de 1990: a experiência cearense" (Textos FCC, Fundação Carlos Chagas, n. 27/07, 2007). E-mail: pzibas@uol.com.br

Recebido em março de 2008 Aprovado em maio de 2008 


\section{Resumos/Abstracts/Resumens}

Dagmar M. L. Zibas

\section{"A Revolta dos Pingüins" e o novo pacto educacional chileno \\ $\mathrm{O}$ artigo resulta de pesquisa desenvolvida no Chile, entre} novembro e dezembro de 2007. Traça um amplo painel do atual debate educacional chileno, estudando algumas características da mobilização estudantil de 2006 (conhecida como "a revolta dos pingüins") e seus desdobramentos legais, políticos e institucionais, de forma a trazer subsídios para a reflexão sobre a nossa própria realidade educacional. Os procedimentos incluíram levantamento de documentos oficiais, pesquisa bibliográfica e de material publicado na mídia, bem como entrevistas com agentes do atual processo de mudança política: líder do movimento estudantil, assessora do sindicato docente, especialista do Ministério da Educação, pesquisadores das políticas educacionais, vinculados a universidades e a outros organismos, e diretores de escolas. Os resultados indicam que o atual vigor do debate chileno, rigorosamente focado no questionamento do modelo educacional vigente - considerado por muitos analistas como altamente mercantilizado e segmentado - tem características de vanguarda e de fina sintonia política com a realidade social e educacional do país, o que pode acabar por impor evidências, vencer ou convencer os resistentes, passando a orientar políticas de diminuição das desigualdades.

Palavras-chave: reforma educacional chilena; revolta dos pingüins

\section{"The Revolt of the Penguins" and} the new Chilean educational pact This article is the result of research carried out in Chile between November and December 2007. It sketches a broad picture of the current Chilean educational debate studying some of the characteristics of the student mobilization in 2006 (know as the "revolt of the penguins") and its legal, political and institutional consequences in order to draw out elements for a reflection upon our own educational reality. The research procedures included a survey of official documents, bibliographic research and an analysis of material published by the media, as well as interviews with agents of the current process of political change: a leader of the student movement, an adviser to the teachers' union, a specialist from the Ministry of Education, researchers of educational policy linked to universities and other organisms and school directors. The results suggest that the current strength of the Chilean debate, rigorously focused on questioning the present educational model - considered by many analysts as highly market oriented and segmented - reveals vanguard characteristics and a fine political synchrony with the social and educational reality of the country which could end by imposing evidence, overcoming or convincing the resistant and coming to orient policies for diminishing inequalities.

Key words: Chilean educational reform; revolt of the penguins

“La Rebelión de los Pingüinos” y el nuevo pacto educacional chileno El artículo resulta de una pesquisa desarrollada en Chile, entre noviembre $y$ diciembre de 2007. Traza un amplio cuadro del actual debate educacional chileno, estudiando algunas características de la movilización estudiantil de 2006 (conocida como "la rebelión de los pingüinos") y sus despliegues legales, políticos e institucionales, de forma para traer subsidios para la reflexión sobre nuestra propia realidad educacional. Los procedimientos incluyeron levantamiento de documentos oficiales, pesquisa bibliográfica y de material publicado en los medios de comunicación, bien como entrevistas con agentes del actual proceso de cambio político: líder del movimiento estudiantil, asesora del sindicato docente, especialista del Ministerio de Educación, investigadores de las políticas educacionales, vinculados a universidades y a otros organismos, y directores de escuelas. Los resultados indican que el actual vigor del debate 
chileno, rigorosamente enfocado en el cuestionario del modelo educacional vigente - considerado por muchos analistas como altamente mercantilizado y segmentado - tiene características de vanguardia y de fina sintonía política con la realidad social y educacional del país, lo que puede acabar por imponer evidencias, vencer o convencer los resistentes, pasando a orientar políticas de disminución de las desigualdades.

Palabras clave: reforma educacional chilena; rebelión de los pingüinos. 